\title{
Uji Daya Hambat Ekstrak Spons Laut (Callyspongia Aerizusa) terhadap Pertumbuhan Bakteri Salmonella Typhi dan Streptococcus Pyogenes
}

\author{
${ }^{1}$ Yuki B. J. Rumampuk \\ ${ }^{2}$ Pemsi M. Wowor \\ ${ }^{2}$ Christi D. Mambo
}
${ }^{1}$ Program Studi Pendidikan Dokter Fakultas Kedokteran Universitas Sam Ratulangi Manado ${ }^{2}$ Bagian Farmakologi dan Terapi Fakultas Kedokteran Universitas Sam Ratulangi Email: 14011101021yukirumampuk@gmail.com

\begin{abstract}
Indonesia has the greatest marine biodiversity due to its coral reef ecosystem. Callyspongia aerizusa is a type of sponges that has bioactive potential as antibacterial, anticancer, and antifungal that has not been widely used. This study was aimed to determine whether sea sponge Callyspongia aerizusa had inhibitory activity against Salmonella typhi and Streptococcus pyogenes. This was an experimental laboratory study with Kirby-Bauer well method. Two types of bacteria were used and each of them was repeated 3 times. The first well formed on the agar medium in 6 Petri dishes was filled with concentrated extract of sea sponge. The second well was filled with ciprofloxacin as the positive control. The third well was filled with aquadest as the negative control. The results showed that the total inhibitory zone diameter of Callyspongia aerizusa extract to Salmonella typhi was $12 \mathrm{~mm}$ (mean of 4 $\mathrm{mm}$ ) and to Streptococcus pyogenes the total inhibitory zone diameter was $18 \mathrm{~mm}$ (mean of 6 $\mathrm{mm}$ ). Conclusion: Sea sponge extract of Callyspongia aerizusa could inhibit the growth of Salmonella typhi and Streptococcus pyogenes but were categorized as weak and moderate respectively. Moreover, their inhibitory activities were weaker than the antibiotic cyprofloxacin.
\end{abstract}

Keywords: inhibition, Kirby-Bauer, sea sponges Callyspongia aerizusa

\begin{abstract}
Abstrak: Indonesia memiliki keanekaragaman hayati laut terbesar karena memiliki ekosistem terumbu karang. Callyspongia aerizusa merupakan salah satu jenis spons yang berpotensi bioaktif sebagai antibakteri, antikanker, antijamur yang belum banyak dimanfaatkan. Penelitian ini bertujuan untuk mengetahui ada tidaknya daya hambat spons laut Callyspongia aerizusa terhadap Salmonella typhi dan Streptococcus pyogenes. Jenis penelitian ialah eksperimental dengan metode sumuran Kirby-Bauer. Pada penelitian ini digunakan 2 jenis bakteri dan tiap bakteri dilakukan pengulangan 3 kali. Sumur pertama yang sudah terbentuk pada media agar di 6 cawan Petri diisi dengan larutan ekstrak pekat spons laut Callyspongia aerizusa. Sumur kedua diisi dengan kontrol positif yaitu siprofloksasin. Sumur ketiga diisi dengan kontrol negatif yaitu akuades. Hasil penelitian memperlihatkan diameter zona hambat total dari ekstrak Callyspongia aerizusa terhadap Salmonella typhi sebesar $12 \mathrm{~mm}$ (rerata 4 $\mathrm{mm}$ ) dan terhadap Streptococcus pyogenes diameter zona hambat total sebesar $18 \mathrm{~mm}$ (rerata $6 \mathrm{~mm}$ ). Simpulan: Ekstrak spons laut Callyspongia aerizusa dapat menghambat pertumbuhan bakteri Salmonella typhi dan Streptococcus pyogenes, namun masih dikategorikan lemah dan sedang, juga masih lebih lemah dibandingkan dengan obat antimikroba siprofloksasin.
\end{abstract}

Kata kunci: daya hambat, Kirby-Bauer, spons laut Callyspongia aerizusa

Indonesia merupakan salah satu negara dengan keanekaragaman hayati (biodiver- sitas) laut terbesar di dunia, karena memiiki ekosistem pesisir yang khas, salah satunya 
yaitu ekosistem terumbu karang (coral refs). Jenis biota laut di daerah tropis Indonesia diperkira-kan 2-3 kali lebih besar dibandingkan dengan biota laut di daerah subtropik dan di daerah beriklim dingin. ${ }^{1-3}$

Spons atau porifera adalah hewan dari phylum porifera yang merupakan salah satu penyusun pada ekosistem pesisir dan laut, terutama pada ekosistem terumbu karang yang mempunyai potensi bioaktif sebagai anti-bakteri, antikanker, antijamur yang belum banyak dimanfaatkan. Sebanyak 850 sampai 1500 spesies spons terdapat di perairan Indonesia. ${ }^{4-11}$ Penelitian yang dilakukan oleh Krisyuninda ${ }^{10}$ pada tahun 2012 tentang isolasi senyawa bioaktif spons Callyspongia sp. dengan metode kromatografi lapis tipis (KLT) mendapatkan bahwa pada spons tersebut terdapat kandungan steroid, alkaloid, flavonoid dan treponoid. Hasil penelitian tersebut didukung oleh hasil penelitian sebelumnya yang dilakukan oleh Cowan $^{11}$ pada tahun 1999 yang menyatakan bahwa dalam ekstrak spons laut Callyspongia sp. terdapat senyawa steroid, alkaloid, flavonoid, dan antrakuinon.

Salmonella typhi adalah salah satu bakteri Gram negatif yang merupakan kuman patogen penyebab demam tifoid, yaitu suatu penyakit infeksi sistemik bersifat akut, ditularkan melalui jalur fekaloral terutama melalui makanan dan air yang terkontaminasi. Gejala tidak spesifik dan biasanya demam, anoreksia, sakit kepala, mialgia, dan konstipasi. Demam tifoid didahului oleh gastroenteritis, yang biasanya sembuh sebelum timbulnya penyakit sistemik. ${ }^{12-14}$

Streptococcus pyogenes adalah bakteri Gram positif yang merupakan salah satu patogen yang banyak menginfeksi manusia. Penyakit yang berhubungan dengan Streptococcus terjadi terutama pada saluran pernapasan (faringitis atau tonsilitis) atau infeksi kulit (pyoderma). ${ }^{15,16}$

Penelitian oleh Warbung et al. ${ }^{3}$ pada tahun 2013 menlaporkan bahwa ekstrak spons laut Callyspongia sp. dapat menghambat pertumbuhan bakteri Staphylococcus aureus. Penelitian ini bertujuan untuk menguji apakah ekstrak spons laut Callyspongia aerizusa dapat menghambat pertumbuhan bakteri Salmonella typhi dan Streptococcus pyogenes.

\section{METODE PENELITIAN}

Jenis penelitian ini ialah eksperimental labortorik di Laboratorium Analisa Farmasi Program Studi Farmasi Universitas Sam Ratulangi Manado.

Alat-alat yang digunakan dalam penelitian ini yaitu: cawan petri, tabung reaksi, gelas ukur, wadah, pinset, oven, inkubator, api bunsen, jarum ose, jangka sorong, timbangan, tabung erlenmeyer, vacuum rotary evaporator, autoclave, laminar air fow, gunting, spidol, kamera, masker dan sarung tangan.

Bahan-bahan yang digunakan dalam penelitian ini yaitu: spons laut Callyspongia aerizusa, bakteri Salmonella Typhi, bakteri Streptococcus pyogenes, NA (Nutrient Agar), $\mathrm{NaCl} 0,9 \%, \quad \mathrm{MHA}$ (Mueller Hinton Agar), akuades, siprofloksasin, larutan $\mathrm{BaCl}_{2} 1 \%$, larutan $\mathrm{H}_{2} \mathrm{SO}_{4}$ $1 \%$ dan akuades.

Pembuatan ekstrak spons laut Callyspongia aerizusa dilakukan menggunakan metode maserasi dengan etanol $96 \%$ selama 24 jam dengan perbandingan 1:2 $(w / v)$. Bagian sisa dari penguapan etanol disebut ekstrak pekat. Esktrak pekat yang dihasilkan sebanyak 5,3 gram.

Alat-alat yang digunakan dalam penelitian ini disterilkan dalam oven pada suhu $170^{\circ} \mathrm{C}$ selama \pm 1 jam (sterilisasi kering). Media disterilkan dalam autoclave sampai suhu mencapai $121^{\circ} \mathrm{C}$ dan tunggu selama 15 menit (sterilisasi basah).

Inokulasi bakteri pada media agar miring. Bakteri uji diambil dengan jarum ose steril, lalu ditanamkan pada media agar miring dengan cara menggores. Selanjutnya diinkubasi dalam inkubator pada suhu $37^{\circ} \mathrm{C}$ selama 24 jam. Perlakuan yang sama dilakukan pada setiap jenis bakteri uji. Standar kekeruhan suspensi bakteri uji menggunakan larutan baku McFarland.

Metode pengujian yang digunakan ialah metode modifikasi Kirby-Bauer dengan menggunakan sumuran. Sumur 
pertama yang sudah terbentuk pada media agar di 6 cawan petri diisi dengan larutan ekstrak pekat spons laut Callyspongia aerizusa yang sudah dilarutkan dengan etanol $96 \%$ dan dievaporasi dengan vacuum rotary evaporator. Sumur kedua diisi dengan kontrol positif yaitu siprofloksasin yang sudah dilarutkan dengan akuades. Sumur ketiga yang merupakan kontrol negatif diisi dengan akuades. Masingmasing diteteskan pada sumur yang berbeda sebanyak $0,2 \mathrm{ml}$. Setelah itu, cawan Petri diinkubasi dalam inkubator pada suhu $37^{\circ} \mathrm{C}$ selama 24 jam.

Pengamatan dilakukan setelah 24 jam. Zona bening merupakan petunjuk adanya daya hambat dari ekstrak spons laut Callyspongia aerizusa terhadap bakteri Salmonella typhi dan Streptococcus pyogenes. Zona hambat yang terbentuk di sekitar sumur diukur diameter vertikal dan diameter horizontal dengan satuan milimeter ( $\mathrm{mm})$ menggunakan jangka sorong (Gambar 1).

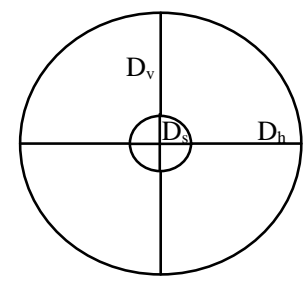

Gambar 1. Pengukuran diameter zona hambat Keterangan :

$\mathrm{D}_{\mathrm{v}} \quad$ : Diameter vertikal

$\mathrm{D}_{\mathrm{h}} \quad$ : Diameter horizontal

$\mathrm{D}_{\mathrm{S}} \quad$ : Diameter sumur

Diameter zona hambat diukur dengan rumus :

$$
\left(\frac{\mathrm{Dv}+\mathrm{Dh}}{2}\right)-7
$$

\section{HASIL PENELITIAN \\ Salmonella typhi}

Zona hambat yang terbentuk pada media perlakuan bakteri Salmonella typhi dapat dilihat pada Gambar 2. Zona hambat yang terbentuk di sekitar sumur yang diberi kontol positif (siprofloksasin) lebih besar daripada zona hambat yang terbentuk di sekitar sumur yang diberi ekstrak spons laut Callyspongia aerizusa.

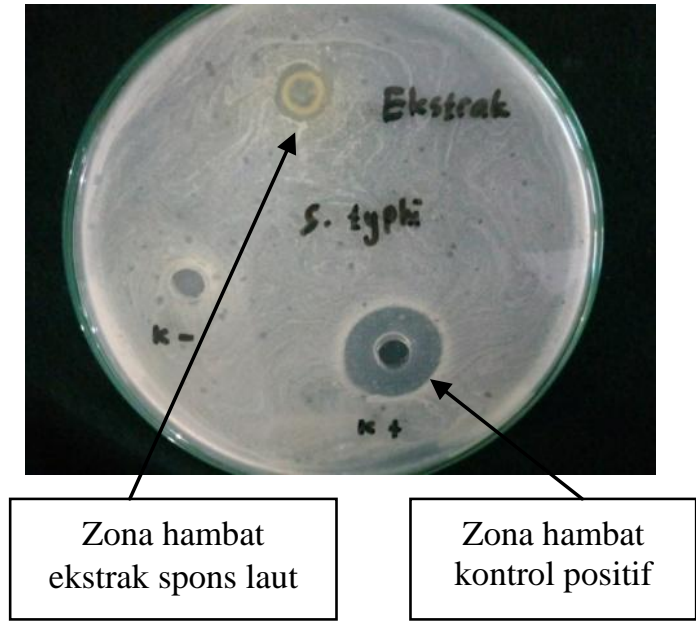

Gambar 2. Zona hambat yang terbentuk terhadap bakteri Salmonella typhi

Perbandingan diameter zona hambat kontrol negatif (akuades), kontrol positif (siprofloksasin), dan ekstrak spons laut terhadap bakteri Salmonella typhi dapat dilihat pada Tabel 1.

Tabel 1. Perbandingan diameter zona hambat kontrol negatif (akuades), kontrol positif (siprofloksasin), dan ekstrak spons laut Callyspongia aerizusa terhadap bakteri Salmonella typhi

\begin{tabular}{cccc}
\hline \multirow{2}{*}{$\begin{array}{c}\text { Cawan } \\
\text { Petri }\end{array}$} & \multicolumn{3}{c}{ Salmonella typhi } \\
\cline { 2 - 4 } & $\begin{array}{c}\text { Kontrol } \\
\text { negatif }\end{array}$ & $\begin{array}{c}\text { Kontol } \\
\text { positif }\end{array}$ & Ekstrak \\
\hline I & 0 & 17,5 & 3,5 \\
II & 0 & 18 & 4,5 \\
III & 0 & 18 & 4 \\
\hline
\end{tabular}

\section{Streptococcus pyogenes}

Zona hambat yang terbentuk pada media perlakuan bakteri Streptococcus pyogenes dapat dilihat pada Gambar 3.

Perbandingan diameter zona hambat kontrol negatif (akuades), kontrol positif (siprofloksasin), dan ekstrak spons laut Callyspongia aerizusa terhadap bakteri Streptococcus pyogenes dapat dilihat pada Tabel 2 yang menunjukkan zona hambat yang terbentuk di sekitar sumur yang diberi kontol positif (siprofloksasin) lebih besar dari zona hambat yang terbentuk di sekitar sumur yang diberi ekstrak spons laut Callyspongia aerizusa. 


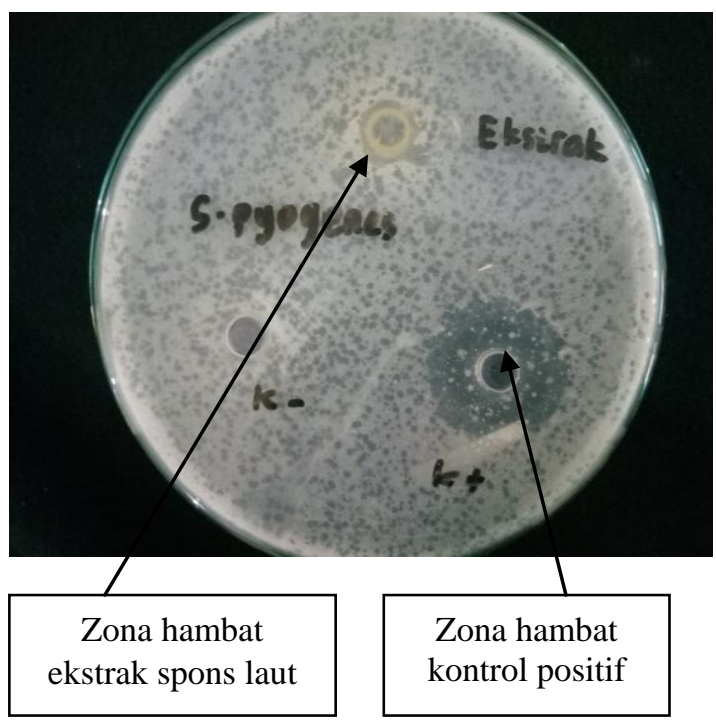

Gambar 3. Zona hambat yang terbentuk terhadap bakteri Streptococcus pyogenes
Tabel 2. Perbandingan diameter zona hambat kontrol negatif (akuades), kontrol positif (siprofloksasin), dan ekstrak spons laut Callyspongia aerizusa terhadap bakteri Streptococcus pyogenes

\begin{tabular}{cccc}
\hline \multirow{2}{*}{$\begin{array}{c}\text { Cawan } \\
\text { Petri }\end{array}$} & \multicolumn{3}{c}{ Streptococcus pyogenes } \\
\cline { 2 - 4 } & $\begin{array}{c}\text { Kontrol } \\
\text { negatif }\end{array}$ & $\begin{array}{c}\text { Kontol } \\
\text { positif }\end{array}$ & Ekstrak \\
\hline I & 0 & 24,5 & 5,5 \\
II & 0 & 21 & 6,5 \\
III & 0 & 24,5 & 6 \\
Total & 0 & 70 & 18 \\
Rerata & 0 & 23,3 & 6 \\
\hline
\end{tabular}

Diameter rerata zona hambat yang terbentuk pada bakteri Streptococcus pyogenes lebih besar dari zona hambat yang terbentuk pada bakteri Salmonella typhi (Tabel 3).

Tabel 3. Perbandingan diameter zona hambat kontrol negatif (akuades), kontrol positif (siprofloksasin), dan ekstrak spons laut Callyspongia aerizusa terhadap bakteri Salmonella typhi dan Streptococcus pyogenes.

\begin{tabular}{ccccccc}
\hline \multirow{2}{*}{ Cawan Petri } & \multicolumn{3}{c}{ Salmonella typhi } & \multicolumn{3}{c}{ Streptococcus pyogenes } \\
\cline { 2 - 7 } & $\mathrm{K}(-)$ & $\mathrm{K}(+)$ & Ekstrak & $\mathrm{K}(-)$ & $\mathrm{K}(+)$ & Ekstrak \\
\hline I & 0 & 17,5 & 3,5 & 0 & 24,5 & 5,5 \\
II & 0 & 18 & 4,5 & 0 & 21 & 6,5 \\
III & 0 & 18 & 4 & 0 & 24,5 & 6 \\
Total & 0 & 53,5 & 12 & 0 & 70 & 18 \\
Rerata & 0 & 17,8 & 4 & 0 & 23,3 & 6 \\
\hline
\end{tabular}

\section{BAHASAN}

Penelitian ini menggunakan metode eksperimental untuk mengetahui daya hambat ekstrak spons laut Callyspongia aerizusa terhadap pertumbuhan bakteri Salmonella typhi dan Streptococcus pyogenes. Dalam penelitian ini digunakan metode sumuran Kirby-Bauer yaitu membuat lubang pada agar padat yang telah diinokulasi dengan bakteri. Jumlah dan letak lubang disesuaikan dengan tujuan penelitian, kemudian lubang diisi dengan ekstrak yang akan diuji. Daerah jernih yang terbentuk di sekitar sumur pada media MHA menunjukkan kemampuan ekstrak spons laut dan kontrol positif dalam menghambat pertumbuhan bakteri.

Metode sumuran dipilih karena mudah dilakukan dan tidak membutuhkan waktu yang banyak. Selain itu, metode difusi dengan sumuran memiliki tingkat sensibilitas lebih tinggi dibanding dengan varian cakram. Adanya partikel tersuspensi pada sampel yang diuji, jauh lebih kecil kemungkinannya untuk menggangu difusi zat antimikroba ke dalam agar daripada pada cakram kertas saring. ${ }^{17}$ Pada penelitian ini, akuades digunakan sebagai kontrol negatif karena merupakan larutan pengencer pada ekstrak spons laut dan 
kontrol positif. Hasilnya, disekitar sumur yang diberi akuades sebagai kontrol negatif tidak ditemukan terbentuknya zona hambat. Hal tersebut membuktikan bahwa terbentuknya zona hambat di sekitar sumur yang diberi ekstrak spons laut Callyspongia aerizusa tidak ada pengaruh dari larutan pengencer.

Antibiotik siprofloksasin digunakan sebagai kontrol positif untuk membandingkan daya hambat antara obat antimikroba dengan ekstrak spons laut. Pemilihan siprofloksasin sebagai kontrol positif karena siprofloksasin merupakan antimikroba spektrum luas. ${ }^{18}$ Pada penelitian ini, didapatkan hasil adanya zona hambat yang terbentuk disekitar sumur. Bila dibandingkan dengan zona hambat yang terbentuk di sekitar sumur yang diberi siprofloksasin, zona hambat ekstrak spons laut Callyspongia aerizusa lebih kecil.

Berdasarkan hasil pengamatan yang dilakukan pada uji daya hambat menunjukkan bahwa dengan pemberian ekstrak spons ke dalam sumur pada media MHA yang sudah diinokulasi dengan bakteri uji didapatkan adanya zona hambat, artinya ekstrak spons laut Callyspongia aerizusa kemungkinan memiliki efek antibakteri terhadap bakteri Salmonella typhi dan Streptococcus pyogenes.

Lebar diameter zona hambat yang terbentuk di sekitar sumur dapat dijadikan sebagai parameter untuk melihat kekuatan senyawa bioaktif yang terkandung dalam spons laut. Semakin luas zona hambat yang terbentuk, maka semakin kuat senyawa bioaktif menghambat pertumbuhan bakteri. Kriteria kekuatan daya hambat sebagai berikut: diameter zona hambat $\leq 5 \mathrm{~mm}$ dikategorikan lemah, zona hambat 5-10 $\mathrm{mm}$ dikategorikan sedang, zona hambat 10$20 \mathrm{~mm}$ dikategorikan kuat dan zona hambat $\geq 20 \mathrm{~mm}$ dikategorikan sangat kuat. ${ }^{19}$ Berdasarkan kriteria tersebut, maka daya hambat ekstrak spons laut Callyspongia aerizusa pada bakteri Salmonella typhi dengan konsentrasi $100 \mathrm{mg} / \mathrm{ml}$ termasuk lemah yaitu $4 \mathrm{~mm}$. Daya hambat ekstrak spons laut Callyspongia aerizusa pada bakteri Streptococcus pyogenes dengan konsentrasi yang sama $100 \mathrm{mg} / \mathrm{ml}$ termasuk sedang yaitu $6 \mathrm{~mm}$.

Terbentuknya zona hambat dipengaruhi oleh kandungan senyawa aktif yang terdapat pada ekstrak spons laut Callyspongia aerizusa. Hal tersebut telah dilaporkan oleh penelitian yang dilakukan oleh Krisyuninda ${ }^{10}$ yang mendapatkan adanya kandungan steroid, alkaloid, flavonoid dan treponoid, yang didukung oleh hasil penelitian sebelumnya oleh Cowan $^{11}$ yang menyatakan bahwa dalam ekstrak spons laut Callyspongia sp. terdapat senyawa steroid, alkaloid, flavonoid, dan antrakuinon.

Mekanisme penghambatan bakteri oleh senyawa steroid diduga dengan cara merusak membran sel bakteri. Steroid dapat meningkatkan permeabilitas membran sel sehingga akan terjadi kebocoran sel yang diikuti dengan keluarnya materi intrasel. ${ }^{11,20}$ Senyawa flavonoid memiliki spektrum aktivitas antimikroba yang luas dan dapat mengurangi kekebalan pada organisme sasaran. Sifat antibakteri senyawa flavonoid ialah dengan menyebabkan terjadinya denaturasi protein di dalam sel bakteri. $^{21,22}$ Mekanisme penghambatan bakteri oleh senyawa alkaloid diduga dengan cara merusak komponen penyusun peptidoglikan pada sel bakteri sehingga lapisan dinding sel tidak terbentuk secara utuh dan menyebabkan kematian sel tersebut. $^{21,23}$

Hasil penelitian ini dibandingkan dengan penelitian yang dilakukan oleh Warbung et al. ${ }^{3}$ yaitu daya hambat ekstrak spons laut Callyspongia sp. terhadap pertumbuhan bakteri Staphylococcus aureus (bakteri gram positif) menunjukkan perbedaan nilai yang cukup bermakna, terutama untuk bakteri uji Streptococcus pyogenes (bakteri gram positif). Hal ini terjadi kemungkinan karena spesies sampel yang digunakan berbeda. Pada penelitian ini yang digunakan ialah Callspongia aerisuza. Menurut penelitian Hanani et al. ${ }^{24}$ pada tahun 2005 tentang identifikasi senyawa antioksidan dalam spons Callyspongia sp. dari Kepulauan Seribu menunjukkan bahwa ekstrak Callyspongia 
sp. hanya mengandung senyawa alkaloid. Dengan demikian dapat disimpulkan bahwa setiap spesies dari Callyspongia sp. memiliki kandungan yang berbeda-beda. Dalam penelitian ini tidak dilakukan analisis fitokimia pada ekstrak spons laut Callyspongia aerizusa sehingga tidak diketahui zat aktif yang terkandung yang dapat menghambat bakteri dan bagaimana mekanisme kerjanya.

Hasil pengukuran juga menunjukkan diameter rerata zona hambat yang terbentuk pada media tanam bakteri Streptococcus pyogenes lebih besar dari pada bakteri Salmonella typhi. Hal ini menunjukkan bahwa bakteri Gram positif lebih rentan terhadap zat aktif dalam ekstrak dibandingkan bakteri Gram negatif, karena perbedaan struktur dinding sel. Bakteri Gram negatif mempunyai dinding sel dengan struktur lipopolisakarida kompleks yang dapat menghalangi penetrasi esktrak ke dalam sel mikroba, sedangkan pada bakteri Gram positif membran luarnya dibentuk oleh lapisan peptidoglikan yang mudah ditembus oleh senyawa aktif dalam bahan uji. ${ }^{14,16,25}$

Penelitian ini menunjukkan bahwa ekstrak spons laut Callyspongia aerizusa dapat menghambat pertumbuhan bakteri Salmonella typhi (rerata diameter zona hambat $4 \mathrm{~mm}$ ) dikategorikan lemah dan Streptococcus pyogenes (rerata diameter zona hambat $6 \mathrm{~mm}$ ) dikategorikan sedang. Daya hambat ekstrak spons laut Callyspongia aerizusa masih lebih kecil dibandingkan dengan obat antimikroba siprofloksasin.

\section{SIMPULAN}

Berdasarkan hasil penelitian dapat disimpulkan bahwa ekstrak spons laut Callyspongia aerizusa dapat menghambat pertumbuhan bakteri Salmonella typhi dikategorikan lemah dan Streptococcus pyogenes dikategorikan sedang. Daya hambat ekstrak spons laut Callyspongia aerizusa masih lebih lemah dibandingkan dengan obat antimikroba siprofloksasin.

\section{SARAN}

Perlu dilakukan analisis fitokimia untuk mengetahui jenis senyawa aktif spons laut Callyspongia aerizusa yang menghambat pertumbuhan bakteri Salmonella typhi dan Streptococcus pyogenes dan bagaimana mekanisme kerjanya.

Perlu dilakukan penelitian selanjutnya mengenai uji daya hambat ekstrak spons laut Callyspongia aerizusa terhadap bakteri Salmonella typhi dan Streptococcus pyogenes pada berbagai konsentrasi kepekatan ekstrak.

\section{DAFTAR PUSTAKA}

1. Darsono P. Pemanfaatan sumber daya laut dan implikasinya bagi masyarakat nelayan. Makalah disajikan dalam Seminar Nasional Pengelolaan Sumber Dayar Kelautan demi Peningkatan Kesejahteraan Rakyat, Jakarta, Indonesia, 1999.

2. Sumaryono W, Wibowo AE, Cahidir. Isolasi dan elsidasi struktur senyawa utama dari sponge axynissa aplysinoides. Majalah Farmasi Indonesia. 2005; 16(4):1113-20.

3. Warbung YY, Wowor VNS, Posangi J. Daya hambat ekstrak spons laut callyspongia sp. terhadap pertumbuhan bakteri Staphylococcus aureus. Jurnal Ilmiah Kedokteran Gigi. 2013;1(2).

4. Suparno. Kajian bioaktif spons laut (porifera: demospongiae) suatu peluang alternatif pemanfaatan ekosistem karang Indonesia dalam dibidang farmasi, Bogor, Indonesia. Makalah pribadi falsafah sains. 2005.

5. Haris A, Arniati, Werorilangi S. Uji antibakteri patogen ekstrak sponge menggunakan metode High Troughput Screening (HTS) dengan indikator MTT (3-[4,5-Dimethylthiazol-2-Yl]2,5-Diphenyltetrazolium Bromide). 2013 [cited 2 Sep 2017]. Available from: Hasanuddin University Jurusan Ilmu Kelautan http://repository.unhas. ac.id/handle/123456789/9769.

6. Haris A, Weorilangi S, Gosalam S, \& Mas'ud, A. Komposisi jenis dan kepadatan sponge (porifera: demospongiae) di kepulauan Spermonde Kota Makasar. Jurnal Biota. 2014;19(1):36-42. 
7. Haris A. Sponge: biologi dan ekologi. Makalah yang tidak dipublikasikan. 2013.

8. Samawi MF, Rani C, Ramli. Keterkaitan antara kondisi oseanografi dengan komposisi jenis dan kepadatan sponge laut di kepulauan Spermonde. Makassar: Faculty of Marine Science and Fishery Hasanuddin University; 2009.

9. Menggelea FP, Posangi J, Wowor MP, Bara R. Uji efek antibakteri jamur endosimbion spons laut callyspongia sp. terhadap bakteri Pseudomonas aeruginosa dan Eschericia coli. eBm. 2015;3(1).

10. Kriyuninda M. Uji toksisitasfraksi spons Callyspongia sp. dengan metode brine shrimp test dari perairan pasir putih situbondo. Surabaya: Institut Teknologi Sepuluh November; 2012.

11. Cowan M. Plant products as antimicrobial agents. Clin Microbiol Rev. 1999;12(4):564-82.

12. Kidgell $\mathbf{C}$, Reichard U, Wain J, Linz B, Torpdahl M, Dougan G, et al. Salmonella typhi, the causative agent of typhoid fever, is approximately 50.000 years old. Journal of Infect Genet Evol. 2002;2:39-45.

13. Vollaard AM, Ali S, van Asten HA, Widjaja S, Visser LG, Surjadi C, et al. Risk factor for typhoid fever and paratyphoid fever in Jakarta, Indonesia. J Am Med Assoc. 2004;291:2607-15.

14. Gianella RA. Salmonella. In: Baron S, editor. Medical Microbiology (4th ed). Galveston (TX): University of Texas Medical Branch at Galveston, 1996.

15. Kusuma SAF. Strepococcus pyogenes. 2010 Mar 5 [cited 27 Agustus 2017]. Available from: http://pustaka.unpad. ac.id/wpcontent/uploads/2011/09/pusta ka_unpad_streptococcus-pyogenes.pdf.
16. Patterson MJ. Streptococcus. In: Baron S, editor. Medical Microbiology (4th ed). Galveston (TX): University of Texas Medical Branch at Galveston, 1996.

17. Valgas C, de Souza SM, Sumania EFA, \& Sumania A. Screening methods to determine antibacterial activity of natural products. Braz J Microbiol. 2007;38:369-80.

18. Ganiswarna S, Setiabudy R, Suryatna FD, Purwantyastuti, Nafrialdi (Editors). Farmakologi dan Terapi (5th ed). Jakarta: Balai Penerbit FKUI, 1995.

19. Davis WW, Stout TR. Disc plate methods of microbiological antibiotic assay. Microbiol. 1971;22(4):659-65.

20. Hardiningtyas S. Aktivitas antibakteri ekstrak karang lunak Sarcophyton sp. yang difragmentasi dan tidak difragmentasi di perairan Pulau Pramuka Kepulauan Seribu [Skripsi]. Bogor: IPB; 2009.

21. Wulandari R, Utami P, Hartanti D. Penapisan fitokimia dan ui aktivitas antibakteri ekstrak etanol herba pulutan (Urena lobata Linn.) Pharmacy. 2009;6(1).

22. Dewanti S. Antibacteri activity of bay leaf infuse (Folia syzygium polyyanthum WIGHT) to Eschericia coliin-vitro. Jurnal Medika Planta. 2011;1(4).

23. Smith AJ, Jackson MS, Bagg J. The ecology of Staphylococcus species in the oral cavity. J Med Microbiol. 2011; 50(11):940-6.

24. Hanani E, Mun'im A, Sakarini R. Identifikasi senyawa antioksidan dalam spons Callyspongia sp. dari Kepulauan Seribu. Majalah Ilmu Kefarmasian. 2005;2(3):127-33.

25. Kayser FH, Bienz KA, Eckert J, Zinkernagel RM. Color Atlas of Medical Microbiology. New York: Thieme, 2005. 